\title{
DIE REPUBLIEK VAN SUID-AFRIKA IN DIE VERANDERDE WERELD
}

\author{
Sy Edele dr. H. Muller, Minister van Buitelandse Sake
}

Die tema van my referaat is die Republiek van Suid-Afrika in die veranderde wêreld. Dis 'n baie wye onderwerp en ek sal slegs sekere aspekte daarvan kan behandel. Ter inleiding wil ek kortliks stilstaan by die sogenaamde veranderde wêreld.

Suid-Afrika se regstreekse optrede op die internasionale terrein dateer vir praktiese doeleindes van die skepping van die Departement van Buitelandse Sake in 1927 af. In daardie beginjare was ons optrede betreklik beperk en in ' $n$ groot mate bepaal deur ons lidmaatskap van die destydse Britse Gemenebes.

\section{Toe en tans}

Die prentjie van veertig jaar gelede verskil van die huidige soos dag en nag. Op daardie tydstip is feitlik alle internasionale aangeleenthede deur 'n paar Westerse lande gereël. Die Verenigde State was toe alreeds 'n belangrike wêreldmoondheid maar het hom in 'n groot mate van die internasionale toneel onttrek, sover dit sake buite die Amerikas betref. Die kommuniste was skaars tien jaar in Rusland aan bewind en as gevolg van hulle eie interne probleme was die rol wat hulle internasionaal kon speel, taamlik beperk. In die Ooste het Japan natuurlik al gaandeweg sy invloed laat geld.

Weliswaar is die Volkebond na die Eerste Wêreldoorlog in die lewe geroep om verdere botsings, veral in Europa, te probeer vermy. Dit is nie my voorneme om hier 'n ontleding van hierdie mislukte poging te maak nie.

Met enkele uitsonderings is feitlik die hele Afrika deur 'n paar Wes-Europese lande geadministreer. Behalwe SuidAfrika, Egipte, Liberië en vir 'n tydperk ook Ethiopië, is nie alleen Afrika se politieke en verdedigingsaangeleenthede nie, maar ook sy interne bestuur deur 'n groepie koloniale moondhede waargeneem. Ons eie verhoudings met Afrika was in die praktyk beperk tot ons verhoudings met hierdie koloniale moondhede. As ons iets oor Afrika wou weet of enige probleme in verband met Afrika gehad het, moes ons in die betrokke Europese hoofstede aanklop. 
Met die beëindiging van die Tweede Wêreldoorlog breek 'n nuwe era aan. In die veertigerjare maak ons kennis met nuwe toestande, nuwe magsverdelings en magsewewigte, nuwe organisasies, nuwe metodiek en, laaste maar nie die minste nie, nuwe probleme. Die ou Volkebond word vervang deur die Verenigde Volke-Organisasie wat op 'n nuwe lees geskoei is. Die verantwoordelikhede en die magsposisie van die groot moondhede is nog erken, maar die Handves het ook groter geleenthede vir die ander moondhede gebied om hulle invloed te laat geld. Vir die suksesvolle uitlewing van die Handves is een uiters vername bestanddeel egter as vanselfsprekend aanvaar, naamlik verantwoordelike optrede deur die groot- sowel as die kleiner moondhede. Hierdie verantwoordelike optrede sou nie alleen eerbiediging van die bepalings van die Handves meebring nie maar sou ook objektiewe en eerlike pogings tot samewerking ter uitskakeling van internasionale wrywing insluit. Met die oog hierop het Suid-Afrika as 'n stigterslid die Handves onderskryf. Sommer uit die staanspoor vind ons egter dat die veranderde wêreld groter veranderings ingehou het as wat op daardie stadium voorsien is.

Die vernaamste Westerse moondhede was uitgeput deur die oorlog, en die Russe het die geleentheid aangegryp om die Weste se invloed verder te verminder deur 'n veldtog op tou te sit vir die beëindiging van kolonialisme. Dit het die kommuniste uitstekend gepas om uit selfsugtige oorwegings op te tree as die kampvegters en bevryders van die onderhorige volke van Asië en Afrika, terwyl niks gerep is van die bevryding van dié volke wat aan Russiese heerskappy onderwerp was nie. Die Westerse koloniale moondhede was nie in staat om hierdie proses te keer nie, veral nadat die V.S.A. en die V.V.O. self ook begin het om hulle daarvoor te beywer, en het dus maar gedwee oorgegaan tot die grootskaalse en oorhaastige likwidasie van hulle koloniale ryke. Die groot aantal onafhanklike state wat sodoende ontstaan het, het vervolgens aanleiding gegee tot die vorming van twee nuwe magsblokke onder aanvoering van die Russe en die Weste, onderskeidelik, wat met mekaar gewedywer het om die guns van die nuwe state te wen.

Hierdie ingrypende verskuiwing in die magsewewig sowel as die intense naywer en botsende belange van die groot moondhede sou spoedig die Veiligheidsraad lamlê. 


\section{Suid-Afrika en die Nuwe Wêreld}

Die wedywering tussen die twee magsblokke, algemeen bekend as die Koue Oorlog, het vir Suid-Afrika verreikende gevolge meegebring - nie alleen in die Verenigde Volke nie, maar ook in Afrika. Die Wes-Europese moondhede het geleidelik van die Afrikatoneel verdwyn, en ons moes feitlik oornag alleen ons pad in die nuwe Afrika vind - Afrika wat ons as 'n witmansland met die kolonialisme van die voorafgaande eeue verwar en vereenselwig het. Die groeiende aantal Afrikastate het hul invloed al meer in die Verenigde Volke laat geld, veral nadat hulle saam met die Asiate oor 'n meerderheid in die Algemene Vergadering beskik het. Westerse lande wat vroeër of ons rassebeleid by implikasie of andersins aanvaar ò geen ag daarop geslaan het nie, begin skielik stelling teen ons inneem as gevolg van die druk wat op hulle uitgeoefen word deur die nuwe Afrika-Asiatiese groep, bygestaan deur die Kommunistiese blok. Aangespoor deur die welslae wat hulle sodoende behaal, verskerp die Afro-Asiate die vete teen Suid-Afrika. In die proses word een fondament van die Handves na die ander afgetakel, tot die stadium bereik word waar die sogenaamde dubbele maatstaf 'n alledaagse verskynsel is, en slegs die aantal beskikbare stemme bepaal in watter mate die Handves en die organisasie se reëls en prosedure veronagsaam kon word.

Gelyktydig hiermee ondergaan die Britse Statebond ook 'n algehele gedaantewisseling. Met sy nuwe uitgebreide lidmaatskap en karakter word sy periodieke konferensies feitlik 'n replika van die Algemene Vergaderings van die Verenigde Volke. Die ou idee van die bevordering van gemeenskaplike belange maak plek vir die beklemtoning van verskille. $U$ is almal bewus van die toedrag van sake wat uiteindelik tot ons uittrede uit die Organisasie gelei het.

Ek wil nie langer by hierdie veranderde wêreld stilstaan nie. Daar is genoeg gesê om aan te dui hoe daadwerklik die verandering was en hoe Suid-Afrika feitlik op sy eentjie sy pad in die nuwe wêreld moes vind. Alleen 'n kerngesonde, beginselvaste en doelgerigte Suid-Afrika kon dit doen, en het dit gedoen. Binne die Verenigde Volke moes en het ons dikwels alleen, soms in die geselskap van een of twee ander state, gewaarsku, heftig beswaar gemaak, en ons met alle mag verset teen pogings om die Handves te versnipper, om na 
willekeur en volgens die wense van die meerderheid, dubbele standaarde toe te pas en in die huishoudelike aangeleenthede van lidstate - veral Suid-Afrika s'n - in te meng. Byna twee dekades lank het ons op die gevare van hierdie tendense gewys, en alhoewel al hoe meer verantwoordelike lande in die jongste tyd die gevaar daarvan begin insien, is die wanpraktyke in die V.V. nog geensins aan bande gelê nie. Alleen verantwoordelike optrede deur dié moondhede wat by magte is om dit te doen, kan die situasie nou nog red.

Desnieteenstaande het ons tog ons plek op internasionale gebied volgestaan en, waar moontlik, en in ons belang, met die internasionale gemeenskap saamgewerk. Ons het ook deurgaans ons gewig in die stryd teen die Kommunisme ingewerp. So het Suid-Afrika byvoorbeeld sy plig nagekom in die Koreaanse Oorlog en die Berlynse Lugbrug, en terselfdertyd verhoed dat die kommuniste 'n wurggreep op Suidelike Afrika kry.

Wat Afrika betref, het ons vroeg reeds besef dat ons ons grootste bydrae kan maak op tegniese en wetenskaplike gebied. Na die Tweede Wêreldoorlog het ons etlike jare lank waardevolle bydraes van hierdie aard deur verskeie organisasies vir samewerking in Afrika gelewer. Tydens die emosionele vlaag wat in die begin van die sestigerjare nie alleen oor Afrika nie maar oor die hele wêreld gewoed het, is ons deelname aan hierdie samewerking egter beëindig. Suid-Afrika het nietemin voortgegaan om die hand van vriendskap na Afrika te reik in die oortuiging dat die dag spoedig sou aanbreek wanneer die nuwe state verplig sou word om kennis te neem van die harde feite van die lewe, en die emosionele benadering sou moes plek maak vir groter realisme.

Intussen was daar vir Suid-Afrika net een weg oop om vas te staan teen die druk van buite, sy eie huis in orde te hou en die voorspoed en sekuriteit van almal wat die Republiek bewoon, te bevorder en te verseker. Die sukses wat op hierdie gebied behaal is, is aan $\mathbf{u}$ almal bekend. Vir die doel van ons bespreking vandag moet ek egter benadruk dat hierdie sukses van ons interne optrede 'n noodsaaklike voorvereiste was vir die uitwaartse poging wat tans angewend word.

\section{Naasbestaan en samewerking}

Dit bring my dan tot die huidige stadium - die stadium 
van Suid-Afrika se optrede in die veranderde wêreld soos ons hom vandag ken.

Aangesien daar tans groot belangstelling in ons Afrikabeleid getoon word, is dit miskien goed dat ek hier begin. Die grondbeginsels van ons benadering is natuurlik nie net tot Afrika beperk nie. Dit geld vir en is deurslaggewend in ons verhoudings met alle state.

Soos algemeen bekend, gaan die Regering uit van die standpunt dat internasionale vriendskap en samewerking te alle tye moet berus op wederkerige respek, die erkenning van die soewereine onafhanklikheid van state, en geen inmenging in ander se huishoudelike sake nie. Verskille in politieke opvattings en benaderings ten opsigte van interne aangeleenthede behoort geen struikelblok vir vrugbare samewerking tussen regerings in sake van gemeenskaplike belang te wees nie. Dit is vanselfsprekend dat geen land daarna moet streef om 'n ander op politieke, ekonomiese of enige ander terrein te oorheers nie. Waar een land ' $n$ ander help, moet die hoofdoel van sodanige hulp wees om die ontvangende land in staat te stel om homself te help. Suid-Afrika is sterk gekant teen enige vorm van neo-kolonialisme of ekonomiese imperialisme. Ons weier konsekwent om in die sake van ander in te meng en verset ons teen alle pogings van ander om hulle met ons sake te bemoei.

Daar is reeds bewys dat ons benadering 'n gesonde een is en besig is om bevredigende resultate te lewer. By gebrek aan persoonlike kennis van Suid-Afrika het die meeste Afrikastate ons voorheen beoordeel en veroordeel volgens die propagandaveldtog wat sedert die Tweede Wêreldoorlog teen ons gevoer is. Maar vandat daar in die jongste tyd nouer kontak met ons onmiddellike buurstate teweeggebring is nadat hulle onafhanklik geword het, het verskeie leiers in Afrika na vore getree wat die moed en staatsmanskap besit om samewerking met Suid-Afrika realisties te benader.

Dit het byna oornag aanleiding gegee tot ' $n$ ongekende verkeer tussen Suid-Afrika en ons buurstate, op amptenaarssowel as ministeriële vlak. Sedert die begin van hierdie jaar was daar byvoorbeeld twee eerste ministers en meer as 'n dosyn ministers uit buurstate in Suid-Afrika op besoek. Afgesien van gereelde nie-ministeriële sendings uit die Republiek na Afrika-state en omgekeerd, het ek self vanjaar samesprekings met hoofman Jonathan in Maseru gevoer, terwyl 
ek verlede jaar die onafhanklikheidsviering van Lesotho en Botswana bygewoon het. Verder het minister Fouché in Juniemaand amptelike besoeke in Botswana en Rhodesië afgelê, terwyl minister Haak onlangs in Mosambiek opgetree het.

Dit is 'n bemoedigende ontwikkeling, want gereelde kontakte van hierdie aard is nie alleen noodsaaklik vir goeie samewerking tussen die Republiek en elkeen van die betrokke state nie, maar op die lang duur moet dit ook verreikende gevolge en voordele vir die hele Suidelike Afrika meebring.

Suid-Afrika verkeer in 'n unieke posisie om 'n wesentlike bydrae tot die ontwikkeling van die kontinent te lewer. Ons is in staat om ander lande in Afrika te help met hulle probleme op wetenskaplike, tegnologiese, ekonomiese, en talle ander gebiede, want deur die eeue heen het ons geleer om self hierdie probleme op te los. Ons is bereid om ons kennis met die Afrika-state te deel, en dit staan hulle vry om ons te raadpleeg en met ons saam te werk. Ons maak daar geen geheim van dat ons glo in samewerking, eerder as in geskenke nie, en beskou dit as 'n voorvereiste vir vrugbare samewerking dat elkeen van die partye bereid moet wees om self skouer aan die wiel te sit en nie moet verwag dat ander sy probleme vir hom oplos nie. Alleen wanneer samewerking en bystand op hierdie grondslag aangebied word, kan dit tot permanente voordeel van onderontwikkelde lande strek en blywende vriendskap bevorder. Op die lang duur sal dit ook tot ons voordeel strek. Dit is immers vanselfsprekend dat bystand wat in hierdie gees verleen word, die vriendskap en trou van andere sal wen, en nie opportunistiese optrede wat op selfsugtige oorwegings berus nie.

Dit is die gesindheid waarin ons reeds met ons bure in Suidelike-Afrika op verskillende gebiede saamwerk. En dit is nie ' $n$ nuwe benadering nie, want ons het dit reeds vantevore gedoen in die geval van organisasies soos die CCTA en die CSA. Ek het reeds in die Parlement en elders voorbeelde gegee van wat vandag in die praktyk plaasvind en wil nie weer op besonderhede ingaan nie. Dit mag $u$ interesseer om te weet dat samewerking nie net op 'n bi-laterale basis plaasvind nie maar ook op 'n multi-laterale basis, byvoorbeeld die gesamentlike onderhandelings wat ons reeds met die Portugese, Botswana en die administrasie van Swaziland oor die gebruik van gemeenskaplike riviere gevoer het. Afgesien van samewerking wat reeds plaasvind en bystand wat reeds ver- 
leen word, is ons feitlik voortdurend in verbinding met Lesotho en ander buurstate oor verdere tegniese en administratiewe hulp, en samewerking t.o.v. arbeidsake, gesondheid, burgerlike lugvaart en 'n verskeidenheid van ander aangeleenthede. Soos bekend, bestaan daar reeds 'n paar organisasies in Suidelike Afrika waar probleme van gemeenskaplike belang gesamentlik aangepak word, soos die bestryding van veesiektes, sprinkane, ens. Vroeër vanjaar is daar in Johannesburg 'n konferensie gereël deur so 'n organisasie wat hom toelê op die bewaring en benutting van die bodem in Suidelike Afrika en bekend staan as SARCCUS. Hierdie konferensie is bygewoon deur verteenwoordigers van al die state van Suidelike Afrika, insluitende Malawi.

Dit behoort op hierdie stadium duidelik te wees dat ons beleid en optrede ten opsigte van die Afrikastate realisties is eerder as dogmaties en volgens die patroon wat tot dusver gewoonlik deur andere gevolg is. Trouens, ek glo dat ons, saam met ons buurstate, besig is om 'n nuwe patroon van naasbestaan en samewerking daar te stel wat navolgenswaardig is, eerstens omdat ons standpunt gebaseer is op die inherente reg tot selfbeskikking van alle volke, d.w.s. een van die algemeen aanvaarde beginsels wat ook in die Handves van die V.V.O. vasgelê is; en tweedens omdat ons besig is om te bewys dat dit prakties uitvoerbaar is.

Namate die Weste bewus word van ons vrugbare samewerking met ander lande van Afrika, is hulle houding en gesindheid teenoor ons ook besig om te verbeter; en ek glo dat dit in toenemende mate sal gebeur. Want ons moet eenvoudig aanvaar dat ons verhoudings met die res van die wêreld grootliks bepaal word deur ons verhoudings met die Afrikastate. Ek wil sover gaan om te beweer dat die meeste Westerse regerings nie werklik so begaan is oor ons binnelandse kleurbeleid as wat hulle soms voorgee nie. Wat hulle wel beïnvloed, indien dit nie deurslaggewend is nie, is ons vermoë, al dan nie, om met ander Afrikastate in vrede saam te leef en saam te werk. En in hierdie verband is ons besig om aan die wêreld heelwat stof tot nadenke te besorg.

Suid-Afrika se mannekrag en middele is egter beperk, en ons sal daarteen moet waak om nie té ambisieus te word en soveel aan te pak dat ons ons eerste en grootste plig en verantwoordelikheid nie behoorlik kan nakom nie, nl. die opheffing en selfbeskikking van die nie-blanke volke binne ons 
eie landsgrense. Dit moet natuurlik altyd die hoogste prioriteit geniet.

Daarom is dit my weloorwoë mening dat ons in die eerste plek moet konsentreer op samewerking in Suidelike Afrika, soos ons trouens, met enkele uitsonderings, besig is om te doen.

Die besondere aard van hierdie subkontinent, en die besondere plek wat dit in Afrika inneem, bring mee dat dit anders benader behoort te word as die res van Afrika. Dit word miskien nie altyd ten volle besef nie. Hier vind 'n mens byvoorbeeld reeds konkrete bewys van vreedsame naasbestaan in die geval van 'n groep van die mees heterogene state wat hulle toevallig in dieselfde wêrelddeel bevind. Dit is voorwaar ' $n$ buitengewone prestasie in Afrika. Deur die invloed van sy voorbeeld kan Suidelike Afrika dus 'n waardevolle bydrae lewer tot groter harmonie en vrugbare samewerking tussen state in die algemeen.

Dit is betreurenswaardig dat daar elemente in die wêreld is wat nie met hierdie gelukkige toedrag van sake genoeë neem nie en tans wanhopige pogings van buite af aanwend om die harmonie te verstoor. $\mathrm{Ek}$ is daarvan oortuig dat hierdie pogings om onrus te saai in die kiem gesmoor sal word. Die Eerste Minister se verklaring kort gelede, laat nie die minste twyfel hieroor nie.

\section{Diplomatieke betrekkinge met Afrikastate}

Dit is die plig en verantwoordelikheid van die Departement van Buitelandse Sake om, in medewerking met ander tegniese Departemente, die Regering se Afrikabeleid te implementeer. Op hierdie stadium dien die Afrika-afdeling van my Departement as die diplomatieke kanaal en koördinerende faktor. Met die moderne lugvervoer is dit vir ons moontlik om binne 'n uur of twee die hoofstede van ons onmiddellike buurstate te bereik. Die telefoonverbindings is goed, en dit is byna net so maklik vir my of een van my amptenare om 'n eweknie in een van hierdie hoofstede te skakel as wat dit is om met 'n Suid-Afrikaanse kollega in 'n ander departement in verbinding te tree. Tot dusver was hierdie masjinerie nog voldoende, maar daar sal wel 'n stadium kom waar Suid-Afrika se belange mag vereis dat ons sal moet oorgaan tot die skepping van permanente diplomatieke sendings veral in die geval van 
state wat nie so dig by die Republiek geleë is nie.

Ek het my reeds in die openbaar hieroor uitgelaat en dit is nie nodig dat ek weer verduidelik dat die bevordering van vriendskaplike verhoudings met nie-blanke state, insluitende diplomatieke betrekkinge, 'n logiese en natuurlike gevolg van ons tradisionele beleid is nie.

Ons besef almal dat in die lig van ons besondere omstandighede die uitruil van diplomate in die geval van bevriende Afrikastate, iets is wat versigtig hanteer sal moet word. Daar sal ook gewaak moet word teen die gevaar dat dit ontaard en misbruik word en meer kwaad doen as goed. U kan daarop reken dat die hele aangeleentheid baie deeglik oorweeg en bestudeer word en dat daar nie oorhaastig of onoordeelkundig opgetree sal word nie. Niks sal gedoen word wat nie tot voordeel van Suid-Afrika sal strek nie, en wat nie noodsaaklik is vir die bevordering van ons eie belange en vriendskaplike verhoudinge met goedgesinde state in Afrika nie.

Let wel, ek sê goedgesinde state, want die Regering sal beslis nie toelaat dat ons 'n herhaling kry van ons ondervinding met die Russiese konsulêre sending wat voorheen in Suid-Afrika was en hulle aan ondermynende bedrywighede skuldig gemaak het nie. So iets kan vermy word, want geen Regering kan verplig word om diplomatieke sendings teen sy sin te ontvang of in sy land te laat aanbly nie. U kan verseker wees dat die Regering nie diplomate met 'n Afrikastaat, of watter ander staat ook al, sal uitruil nie, tensy die betrokke staat afdoende bewys gelewer het van sy begeerte om alleen vriendskaplike verhoudinge met Suid-Afrika te bevorder en tensy sodanige staat die erkende beginsel van nieinmenging in ander se sake ten volle onderskryf en in die praktyk uitleef nie.

Maar afgesien van die risiko van ondermyning waarteen gewaak sal moet word, mag daar aanvanklik ander probleme ontstaan wat myns insiens nie onoorkomelik behoort te wees nie. Ons moet ook nie uit die oog verloor nie dat verskeie nie-blanke lande vandag verteenwoordigers in Suid-Afrika het en hulle reeds baie jare lank hier gehad het. Trouens voor die oorlog het Indië ook 'n diplomatieke verteenwoordiger in Suid-Afrika gehad en tot 'n paar jaar gelede was hier 'n permanente Egiptiese gesantskap.

Ek mag terloops daarop wys dat diplomate feitlik dwarsdeur die wêreld moeilikheid ondervind met huisvesting in die 
vreemde hoofstede waar hulle hulle tydelik moet vestig. In Suid-Afrika word die posisie, uit die diplomate se standpunt gesien, miskien nog verder bemoeilik omdat hulle verplig is om huisvesting in al twee ons hoofstede te vind. In verskeie dele van die wêreld is daar van tyd tot tyd pogings aangewend om die diplomate se posisie te verlig. Die Regering van Brasilië het byvoorbeeld by die uitlê van hulle nuwe hoofstad, Brasilia, die probleem probeer oplos deur 'n spesifieke deel van die nuwe hoofstad te reserveer vir diplomatieke sendings. In hierdie diplomatieke voorstad word geskikte persele onder sekere voorwaardes aan bevriende regerings beskikbaar gestel waar hulle ambassades en kanselarye kan oprig. Ek het verlede jaar die mooi perseel besigtig wat aldaar aan ons toegesê is. Die Suid-Afrikaanse Regering is besig met 'n soortgelyke skema. Die voorneme is om twee voorstede, een by Pretoria en een by Kaapstad uit te lê, waar huisvesting vir hoofde van sendings en hulle personeel opgerig sal kan word. $\mathrm{Ek}$ is bly om te kan sê dat die ondersoek in hierdie verband reeds ' $n$ gevorderde stadium bereik het. Dit sal in 'n dringende behoefte voorsien en ek vertrou dat dit algemeen verwelkom sal word.

\section{Samowerking met die res van die wêreld}

Maar om terug te keer tot my hooftema: ons pogings om nouer met die buitewereld saam te werk is nie net op Afrika toegespits nie. Spesiale aandag word byvoorbeeld ook geskenk aan ons verhoudinge met ons trans-Atlantiese bure in SuidAmerika, met etlikes van wie ons reeds baie jare diplomatieke en konsulêre betrekkinge het. Diplomatieke betrekkinge is terloops in die jongste tyd met nog twee Latyns-Amerikaanse lande aangeknoop, naamlik Paraguay en Boliwië, en verdere uitbreiding staan voor die deur.

Verlede jaar was ek die amptelike gas van vier regerings in daardie deel van die wêreld, naamlik Argentinië, Paraguay, Brasilië en Uruguay. Die ontvangs wat ons geselskap daar te beurt geval het, was besonder gulhartig. Dit het my veral getref dat die regerings sonder uitsondering, net soos ons, groot waarde heg aan die beginsel van nie-inmenging in ander se sake en bereid is om goeie buurskap te beoefen en met ons saam te werk op 'n basis van wedersydse respek, afgesien van verskille ten opsigte van interne beleid. Die reaksie op my 
besoek was baie bemoedigend. Kort nadat ek daar was, het die Brasiliaanse Regering byvoorbeeld 'n amptelike handelsending na Suid-Afrika gestuur en het Brasilië die eerste keer aan die Randse Paasskou deelgeneem. Later vanjaar sal drie skepe van die Suid-Afrikaanse vloot 'n besoek aan Argentinië aflê. Daar word reeds onderhandel oor 'n regstreekse en gereelde lugdiens tussen die Republiek en Suid-Amerika, wat hopelik in die nabye toekoms ingestel sal word. Verder het die Suid-Afrikaanse Regering verskeie beurse ingestel om dit vir studente uit sekere Suid-Amerikaanse lande moontlik te maak om nagraadse werk aan ons universiteite te doen. Brasilië het hierop reageer deur 'n soortgelyke beurs vir SuidAfrikaanse studente in te stel. Ek hoop dat hierdie beurse op die lang duur o.a. nouer tegniese, wetenskaplike en kulturele samewerking met die betrokke lande in die hand sal werk Daar word ook spesiale pogings aangewend om die handel tussen die Republiek en Suid-Amerikaanse lande te bevorder. Ons is byvoorbeeld besig om ons handelsverteenwoordiging aldaar uit te brei. 'n Sending van die Suid-Afrikaanse Buitelandse Handelsorganisasie (SAFTO) het onlangs 'n geslaagde besoek aan sekere lande in Suid-Amerika afgelê, en Suid-Afrika sal in Oktober deelneem aan die internasionale handelskou in Peru. Ook in die private sektor is daar aanduidings van toenemende belangstelling en groter bedrywigheid in verband met Suid-Amerika.

'n Ander wêrelddeel waar ons 'n mate van vordering maak, is die Ooste. Dit geld veral die uitbreiding van handelsbetrekkinge, soos blyk uit die gereelde handelsendings na en uit die Ooste. Onder andere het twee amptelike handelsendings uit Suid-Korea en Formosa vroeër vanjaar geslaagde besoeke aan Suid-Afrika afgelê. Die bestaande bande tussen Suid-Afrika en Australië en Nieu-Seeland is geensins benadeel deur ons uittrede uit die Statebond nie, en die onlangse instelling van 'n gereelde straaldiens na Australië, kan ons verhoudings alleen bevorder.

Ten spyte van groter bedrywighede in ander dele van die wêreld, word die bande met ons tradisionele Westerse vriende nie verwaarloos nie. Dit blyk o.a. uit die feit dat ek die afgelope paar jaar die meeste Wes-Europese lande as Minister van Buitelandse Sake besoek het. Ander Ministers van die Republiek het ook in die jongste tyd 'n groot aantal Westerse lande besoek. Orals waar ons was, is ons goed ont- 
vang en het ons belangrike kontakte met lede van die betrokke regerings aangeknoop. Al hierdie besoeke was uiters waardevol. Aan die ander kant het ministers, amptenare en ander hooggeplaaste persone uit verskeie lande van Europa, Suid-Afrika in die jongste tyd besoek. Soos bekend was minister Lücke, die Minister van Binnelandse Sake van WesDuitsland, en dr. Franco Nogueira, die Buitelandse Minister van Portugal, vroeër vanjaar hier as gaste van die Suid-Afrikaanse Regering. Daar bestaan geen twyfel dat hierdie twee besoeke ons verhoudinge met die twee lande, wat al twee historiese vriende van Suid-Afrika is, sal bevorder en die bestaande bande sal versterk nie. Later in die jaar en volgende jaar sal meer sulke besoeke deur lede van bevriende Westerse regerings aan die Republiek afgelê word.

$\mathrm{Ek}$ is besonder bly dat ek in staat is om vandag hier aan te kondig dat die Belgiese Minister van Vervoer, mnr. Alfred Bertrand, en sy eggenote, op die 9e September per vliegtuig in Suid-Afrika op besoek sal arriveer as die gaste van die Suid-Afrikaanse Regering. Hulle sal vergesel word deur mnr. Gordts, die Minister se Chef du Cabinet, en mev. Gordts. Minister Bertrand en sy geselskap sal op die 28e September na België terugkeer. Ons sien daarna uit om hulle in die Republiek te verwelkom en hoop dat hulle verblyf hier aangenaam, interessant en nuttig sal wees.

Afgesien van die toenemende kontak op regerings- en diplomatieke vlak, is daar voortdurend 'n wisselwerking tussen Suid-Afrika en die volke van Wes-Europa op feitlik alle terreine van die lewe. Dit wissel van toerisme en immigrasie tot kuns en kultuur, onderwys, wetenskap, tegnologie, en talle ander gebiede. Ons het byvoorbeeld kulturele en wetenskaplike attachés by ons Ambassades in verskeie Westerse hoofstede. Die handel speel natuurlik altyd 'n vername rol in die bepaling van die verhoudinge tussen state. Die feit dat ons cen van die twaalf vernaamste handelslande in die wêreld is, bevorder noodwendig ons goeie verhoudings met dié Westerse lande wat oor baie jare ons handelsvennote geword het en in wie se ekonomie die handel met Suid-Afrika 'n belangrike faktor is.

Ons verhoudinge met die Verenigde State van Amerika word ongelukkig bemoeilik deur sekere wrywingspunte wat die gevolg is van hulle obsessie en verleentheid met hulle eie kleurvraagstuk. Ons probeer egter om te konsentreer op die 
baie punte van gemeenskaplike belang wat ons met die Verenigde State het. My jaarlikse besoeke aan New York vir die VVO-sittings, stel my in staat om mnr. Dean Rusk en van sy kollegas gereeld te ontmoet en sake openhartig met hulle te bespreek. Die regering van die Verenigde State is dan ook deeglik bewus van Suid-Afrika se standpunt in verband met belangrike vraagstukke, soos byvoorbeeld die kommunistiese gevaar, Suidwes-Afrika, Rhodesië, ens. Hulle besef ook terdeë dat ons geen opportuniste is nie maar volgens vaste beginsels optree en dus nie bereid is om na ander se pype te dans nie.

\section{Inligting}

Van wat ek reeds gesê het, behoort dit duidelik te wees dat daar by Suid-Afrika geen begeerte is om sy voortbestaan in isolasie te soek nie, soos soms deur ons kritici beweer word. Die Eerste Minister het hom onlangs by verskillende geleenthede hieroor uitgelaat. Hy het o.a. daarop gewys dat die Regering geensins bereid is om ons beginsels en lewenswyse in hierdie proses prys te gee nie. Die Eerste Minister het trouens onomwonde beklemtoon dat die wêreld ons moet aanvaar soos ons is. Ons het ook geen begeerte om ons opvattings op ander af te dwing nie. Ons skaam ons nie vir ons beginsels of ons dade nie. Ons het niks om te verberg nie. Ons besef dat waar daar soms soveel bitterheid teen ons bestaan, dit dikwels te wyte is aan onkunde. Ons beskou dit dus as ons plig om Suid-Afrika se saak te stel, waar ons dit ook al met voordeel en met waardigheid kan doen.

Soos aangekondig, is ons reeds besig om ander regerings en sekere internasionale organisasies stelselmatig oor die werklikhede in Suid-Afrika in te lig. Ons doen dit nie omdat ons verantwoording aan iemand verskuldig is nie, maar om die ware beeld van Suid-Afrika oor te dra in die vaste geloof dat almal wat bereid is om objektief te wees, onder die indruk sal kom van wat ons beoog en wat hier gedoen word, d.w.s. wat ons motiewe en doelstellings is en hoeveel sukses ons besig is om te behaal en reeds behaal het.

Gebrek aan tyd laat my nie toe om hier op die SuidwesAfrika-aangeleentheid in te gaan nie. In opvolging van wat ek pas gesê het, wil ek net meld dat ons enige maande gelede die Suidwes-Afrika-oorsig gepubliseer en versprei het. 
Dis vrywillig aan regerings en ander instansies dwarsdeur die wêreld gestuur, sonder enige erkenning van 'n verpligting aan ons kant om dit te doen. Hierin verskyn daar 'n massa inligting en besonderhede oor ons doen en late en prestasies in die gebied. Daarbenewens het ons aan regerings wat permanente missies in die Republiek het, ' $n$ verdere geleentheid gebied om hulle verteenwoordigers na Suidwes-Afrika te stuur. Sommige van hulle het reeds van hierdie fasiliteite gebruik gemaak. ' $n$ Mens is verbaas dat almal die gulde geleentheid om eerstehandse kennis oor Suidwes-Afrika op te doen, nie onmiddellik aangegryp het nie, en vra jouself af of dit opregte belangstelling in die lot van die gebied en sy inwoners weerspieël.

\section{Volhard met vasberadenheid}

Aan die begin het ek daarop gewys dat my onderwerp so wyd is dat dit nie moontlik sal wees om alle aspekte daarvan volledig te behandel nie. Ek het probeer aandui dat Suid-Afrika se houding en optrede teenoor die buitewêreld deurgaans deur vaste beginsels bepaal word, en dat die praktiese toepassing en uitleef van daardie beginsels reeds met 'n mate van welslae bekroon word. En alhoewel die sukses wat ons nou uiteindelik besig is om te behaal, op hierdie stadium nog beperk is, sal dit ons aanspoor om te volhard en voort te gaan op die weg wat ons ingeslaan het.

Ons sal dit doen in die hoop en vertroue dat die verantwoordelike lede van die internasionale gemeenskap, sowel as die vyande van Suid-Afrika, in toenemende mate verplig sal word om hulle houding teenoor ons in hersiening te neem. Dit is slegs nodig dat hulle die lesse van die geskiedenis ter harte neem.

Diegene wat ten spyte van mislukkings volhard in hulle pogings om Suid-Afrika deur boikotte en sanksies te isoleer, en ons langs hierdie weg voëlvry te laat verklaar, moet onthou dat geen staat of regering ooit bereid was om teen sy eie nasionale belange op te tree, in die hoop om sodoende 'n twyfelagtige vriend en bondgenoot se guns te wen nie.

Maar dit is ook noodsaaklik dat sekere Westerse moondhede, wat Suid-Afrika se natuurlike bondgenote en vriende behoort te wees, hulle houding teenoor ons hersien in die lig van die gebeure van die afgelope jare, selfs die afgelone 
maande. Ons het onlangs nog gesien dat die Suezkanaal die tweede keer binne tien jaar vir die wêreld se skeepvaart gesluit is - en alle aanduidings is dat dit nog lank gesluit sal bly. Al die verwikkelings in die Nabye Ooste, veral die aanwesigheid van die Russiese vloot in die Middellandse See, kan tog seker by niemand die minste twyfel laat dat hierdie belangrike verbindingskanaal in die toekoms onbetroubaarder as ooit sal wees nie. Dit is eenvoudig onbegryplik dat sekere toonaangewende Westerse moondhede onder sulke omstandighede so 'n kortsigtige en onlogiese houding inneem teenoor die enigste moondheid wat in staat en bereid is om die alternatiewe seeroete na die Ooste te beveilig. Dit is tyd dat hierdie moondhede tot besinning kom, in hulle eie belang en in belang van die vrye wêreld.

Suid-Afrika het geen begeerte om agter 'n granietmuur te skuil nie. Ons strewe na internasionale samewerking en goeie verhoudinge volgens beproefde grondbeginsels wat ek uiteengesit het. Ons soek hierdie vriendskap en medewerking nie in 'n gees van angs nie, ons soek dit omdat ons besef dat internasionale samewerking tot alle partye se voordeel strek, die vrede bevorder en die wêreld 'n gelukkiger en veiliger plek maak. Ons doen dit in die besef dat onenigheid en struweling op die lang duur slegs tot botsings en selfs tot wapengeweld kan lei. Ons besef egter ook dat ten einde vriendskap en samewerking te soek en te vind, ons eerstens sterk moet wees in onsself. As al ons pogings en inspanning tevergeefs sou wees en daarop sou uitloop dat ons ons land fisies moet verdedig, moet en sal Suid-Afrika ook in staat wees om dit met vasberadenheid en in eensgesindheid te doen. Dit is in hierdie gees dat ons die toekoms in 'n veranderde wêreld met vertroue tegemoet gaan. 